\title{
ANALISIS KEBUTUHAN PENGEMBANGAN BUKU AJAR KETERAMPILAN MENULIS BAHASA MANDARIN
}

\author{
Aprilia Ruby Wikarti, Vanya Zelia \\ Program Studi Pendidikan Bahasa Mandarin \\ Fakultas Bahasa dan Seni \\ Universitas Negeri Jakarta
}

\begin{abstract}
Abstrak
Buku ajar umum digunakan sebagai salah satu sarana untuk menyampaikan kurikulum pembelajaran. Isi dan struktur buku ajar sangatlah penting agar tujuan dan target pembelajaran tercapai. Pengembangan buku ajar memerlukan pengetahuan mengenai buku ajar seperti apa yang dibutuhkan. Dengan demikian, perlu dilakukan penelitian analisis kebutuhan untuk mengumpulkan informasi mengenai kebutuhan buku sebagai dasar merancang buku ajar. Analisis kebutuhan adalah suatu cara atau metode untuk mengetahui perbedaan antara kondisi yang ada (kenyataan) dengan kondisi yang diinginkan atau diharapkan atau seharusnya. Dengan demikian, perlu dilakukan sebuah penelitian analisis kebutuhan untuk memahami dan mengumpulkan informasi mengenai kebutuhan buku keterampilan, salah satunya adalah menulis. Buku ajar yang digunakan untuk mata kuliah Menulis sama dengan buku ajar yang digunakan untuk mata kuliah Membaca. Pada seri pertama buku tersebut, tidak terdapat penjelasan sejarah perkembangan aksara Han. Selain itu, juga tidak terdapat penjelasan tentang radikal aksara Han, serta contoh radikal yang terdapat pada buku tidak terlalu beragam.

Menulis adalah sebuah kegiatan mengutarakan atau menyampaikan maksud secara tertulis. Kemampuan tersebut dapat dilakukan hanya jika seseorang memiliki dasar pengetahuan bahasa yang cukup baik. Keterampilan menulis adalah keterampilan yang harus dilatih secara berulang dan berkesinambungan. Pengajaran menulis bahasa Mandarin dimulai dari yang mudah atau sederhana hingga yang sulit, mengajarkan guratan dan radikal, aksara, kata, kalimat, paragraf, hingga wacana. Penelitian ini mencakupi pengumpulan informasi dan identifikasi buku keterampilan menulis yang digunakan PSPBM FBS UNJ dan prodi di universitas lain yang menyelenggarakan pengajaran bahasa Mandarin di Indonesia.

Hasil penelitian ini berupa informasi yang ada serta yang diinginkan pengguna buku keterampilan menulis bahasa Mandarin. Untuk keterampilan menulis, terdapat prodi yang menggunakan buku ajar terbitan Beijing Language and Culture University Press, namun demikian terdapat pula prodi yang menggunakan buku ajar tambahan selain buku tersebut. Selain itu, terdapat pula prodi yang menyusun kompilasi buku ajar. Hal ini disebabkan buku ajar yang sudah ada belum sesuai dengan capaian pembelajaran mata kuliah keterampilan Menulis pada prodi tersebut. Informasi tersebut bermanfaat sebagai masukan-untuk-pengembangan buku ajar mata kuliah Menulis.
\end{abstract}

Keywords: analisis kebutuhan, bahan ajar, menulis, bahasa Mandarin 


\begin{abstract}
Textbooks are used as a means to convey learning curricula. The content and structure of textbooks are very important so that learning objectives and targets can achieved. Developing textbooks requires knowledge of textbooks that needed. Thus, needs analysis need to be done to understanding and gathering information about the needs of books as a basis for designing textbooks. Needs analysis is a way or method to find out the difference between existing conditions (reality) with the desired or expected or supposed conditions.

Writing is an activity to express or convey written intent. This ability can be done only if someone has a fairly good basic knowledge of language. Writing skills are skills that must be practiced repeatedly and continuously. The teaching of Mandarin writing starts from easy(simple) to difficult, teaches strokes and radicals, letters, words, sentences, paragraphs, to discourse.

This research includes gathering information and identifying writing skills books used by PSPBM FBS UNJ and study programs at other universities that conduct Mandarin language teaching in Indonesia. The results of this study are information about existing conditions as well as what language users want. This information is useful as input regarding the development of writing textbooks.
\end{abstract}

Keywords: need analysis, teaching material, writing, Mandarin language

\title{
A. PENDAHULUAN
}

Salah satu tantangan yang dirasa mendesak untuk segera diatasi adalah ketiadaan buku ajar yang dapat mengakomodasi kebutuhan kegiatan pembelajaran bahasa Mandarin di Program Studi Pendidikan Bahasa Mandarin (selanjutnya disingkat PSPBM), Fakultas Bahasa dan Seni (selanjutnya disingkat FBS), Universitas Negeri Jakarta (selanjutnya disingkat UNJ), terutama buku ajar keterampilan bahasa Mandarin yang meliputi empat keterampilan berbahasa yaitu menyimak, berbicara, membaca dan menulis, serta buku tata bahasa sebagai buku pengetahuan bahasa Mandarin.

Sampai saat ini, buku ajar yang digunakan pada kegiatan pembelajaran bahasa Mandarin di PSPBM UNJ adalah seri buku ajar Hanyu Jiaocheng terbitan Beijing Language and Culture University Press. Buku ini merupakan buku ajar bahasa Mandarin bagi mahasiswa asing. Buku ini dibagi menjadi tiga jenjang, yaitu jenjang pertama, kedua, dan ketiga. Selama penggunaan buku ajar tersebut, terdapat berbagai persoalan yang mendesak untuk segera diatasi yaitu: (1) pengadaan buku ajar yang harus diimpor dari Cina, aturan bea cukai, dan perhitungan harga buku ajar yang terus bertambah tinggi seiring dengan meningkatnya nilai kurs yuan terhadap rupiah; (2) kerunutan materi dan penyajian buku ajar kurang tepat bagi mahasiswa PSPBM FBS UNJ sebagai pengguna bahasa Indonesia; (3) bahasa pengantar pada bagian penjelasan kosa kata,-tata bahasa, dan penjelasan lain menggunakan bahasa Mandarin dan bahasa Inggris, sehingga mahasiswa sering mengalami kesulitan untuk memahaminya. Oleh karena itu, PSPBM FBS UNJ memutuskan untuk mengembangkan seri buku ajar untuk keterampilan menulis bahasa Mandarin.

Tarigan (2008: 22) dalam bukunya yang berjudul "Menulis Sebagai Suatu Keterampilan Berbahasa" menyatakan melukis gambar bukanlah menulis. Terkait dengan aksara Han yang diturunkan dari bentuk gambar, seseorang dapat melukis aksara Han, akan tetapi hal tersebut belum dapat dikategorikan bahwa orang tersebut mampu menulis bahasa Mandarin jika dia tidak memahami aksara dan aturan-aturan bahasa Mandarin. 
Zhao dalam "Hanyu Keyi Zheyang Jiao - Yuyan Jineng Pian" menyatakan menulis adalah sebuah kegiatan mengutarakan atau menyampaikan maksud secara tertulis. Kemampuan tersebut dapat dilakukan hanya jika seseorang memiliki dasar pengetahuan bahasa yang cukup baik. Keterampilan menulis adalah keterampilan yang harus dilatih secara berulang dan berkesinambungan. Pelatihan keterampilan menulis dilakukan berdasarkan petunjuk dan arahan pengajar. Pengajar harus memberikan arahan atau panduan dengan benar dan jelas, agar latihan yang dilakukan dapat berjalan dengan baik, terarah, dan tepat. Pengajaran menulis bahasa Mandarin dimulai dari yang mudah hingga yang sulit, yang sederhana hingga yang rumit, dimulai dari mengajarkan guratan dan radikal, aksara, kata, kalimat, paragraf, hingga wacana.

Penelitian ini mencakupi pengumpulan informasi dan identifikasi buku-buku keterampilan menulis yang digunakan PSPBM FBS UNJ dan prodi di universitas lain yang menyelenggarakan pengajaran bahasa Mandarin di Indonesia. Penelitian dilaksanakan dengan berbasis Research and Development. Penelitian dibagi menjadi tiga tahap, yaitu : 1) tahun 2017: Analisis Kebutuhan; 2) tahun 2018: Analisis materi; dan terakhir tahap 3) penyusunan buku ajar. Penelitian mencakupi (1) informasi serta identifikasi buku-buku ajar yang digunakan oleh Prodi bahasa Mandarin di Perguruan Tinggi lain yang ada di Indonesia dalam pengajaran Menulis Bahasa Mandarin; dan (2) tdentifikasi masalah kebutuhan buku ajar Menulis Bahasa Mandarin dari sudut pandang mahasiswa, pengampu mata kuliah, dan dari sudut pandang kaprodi/korprodi sebagai manajermen/pengelola prodi. Penelitian analisis kebutuhan ini mutlak dilakukan agar mendapatkan informasi untuk memahami hal-hal yang berkaitan dengan kebutuhan buku ajar, sehingga hasil analisis kebutuhan selanjutnya dapat menjadi landasan dalam kegiatan analisis materi ajar, serta perancangan dan penyusunan buku ajar.

Rumusan masalah penelitian ini adalah buku ajar yang digunakan pada mata kuliah $\mathrm{P}$ Menulis Bahasa Mandarin di Prodi Pendidikan Bahasa Mandarin pada Perguruan Tinggi yang ada di Indonesia, tingkat kepuasan dosen pengampu, mahasiswa, pengelola (manajemen) prodi terhadap buku ajar yang dipergunakan, kelebihan dan kekurangan buku ajar mata kuliah Menulis Bahasa Mandarin yang dipergunakan menurut pengguna (dosen pengampu, mahasiswa, dan pengelola prodi) buku ajar tersebut.

Hasil penelitian ini diharapkan secara teoretis memberikan dasar pengetahuan dan pemahaman tentang buku ajar keterampilan menulis bahasa Mandarin yang digunakan oleh universitas-universitas saat ini. Pembaca dapat mengetahui karakteristik, kebutuhan, serta tuntutan mahasiswa, dosen atas buku ajar yang digunakan pada pengajaran keterampilan menulis. Selain itu, diharapkan dapat digunakan untuk dasar pengembangan dan pengujian buku ajar keterampilan menulis. Secara praktis hal tersebut tentu akan bermanfaat bagi para peneliti lain, dosen, penulis buku, serta mahasiswa dalam memilih dan menentukan buku ajar yang akan digunakan untuk pengajaran keterampilan menulis.

\section{B. KAJIAN TEORI}

\section{Prinsip Penulisan Bahan Ajar}

Zhou (2009: 270-276) menyatakan penulisan bahan ajar harus berdasarkan beberapa prinsip dan standar yaitu sebagai berikut.

1. Berdasarkan prinsip ilmu pengetahuan. Bahan ajar harus sesuai dengan prinsip pembelajaran bahasa asing sebagai bahasa kedua. Bahan ajar harus dimulai dari yang 
mudah kemudian yang lebih sulit, harus sesuai dengan standar keadaan nyata siswa, mudah diajarkan oleh pengajar serta mudah dipahami oleh siswa.

2. Berdasarkan prinsip kegunaan. Pengajaran bahasa asing sebagai bahasa kedua adalah pengajaran yang melatih keterampilan berbahasa yang dimiliki oleh siswa. Teori yang disampaikan harus dapat membantu pelatihan keterampilan berbahasa tersebut. Hanya buku ajar yang praktis sesuai kegunaan yang dapat menarik minat belajar siswa dan membantu siswa menguasai keterampilan berbahasa.

3. Berdasarkan prinsip sasaran (sesuai kebutuhan dan tujuan belajar siswa). Penyusunan dan penulisan bahan ajar harus sesuai dengan kondisi dan kebutuhan belajar siswa, sesuai dengan karakteristik dan tuntutan siswa.

4. Berdasarkan prinsip minat. Bahan ajar harus dapat menarik minat siswa dan pengajar barulah pembelajaran dapat berjalan dengan menyenangkan.

Selain prinsip-prinsip tersebut, penyusunan dan penulisan bahan ajar haruslah memiliki ciri khas yang menjadikan bahan ajar tersebut berbeda dengan bahab ajar lain, serta inovasi yang dapat menghasilkan kreativitas siswa, sehingga pembeajaran lebih menyenangkan. Dengan demikian bahan ajar tersebut selain berguna dan bermanfaat juga diakui keberadaannya.

\section{Pengembangan Bahan Ajar}

Sebuah buku ajar memiliki kualitas tertentu dan dapat dikategorikan menjadi dua, yaitu: yang berkualitas baik dan kurang baik. Untuk menentukan kualitas buku ajar, buku ajar harus melalui serangkaian pengembangan.

Tarigan (2008: 22) dalam bukunya yang berjudul "Menulis sebagai Suatu Keterampilan Berbahasa" menyatakan melukis gambar bukanlah menulis. Terkait dengan aksara Han yang diturunkan dari bentuk gambar, seseorang dapat melukis aksara Han,tetapi hal tersebut belum dapat dikategorikan bahwa orang tersebut mampu menulis bahasa Mandarin jika dia tidak memahami aksara dan aturan-aturan bahasa Mandarin.

Pada pembelajaran bahasa, hal yang pertama kali dipelajari memang bukanlah bahasa tulisan, melainkan bahasa lisan. Akan tetapi, bahasa tulisan mampu mengatasi keterbatasan yang ditimbulkan oleh keterbatasan komunikasi, perbedaan ruang dan waktu. Bahasa tulisan diwakili oleh kode bahasa berupa aksara. Manusia menggunakan bahasa tulisan untuk menyampaikan ide, maksud, perasaan.

Kegiatan menulis selain melibatkan ide gagasan penulis, juga melibatkan gerakan organ tubuh yang lain, yaitu tangan dan mata. Tulisan adalah bentuk keluaran tertulis yang ingin disampaikan oleh manusia, merupakan sebuah proses transfer dan pengkodean sistem pengetahuan yang rumit, juga merupakan sebuah proses penalaran yang rumit (Chen, 2005: 210).

Pembelajaran keterampilan menulis bahasa Mandarin untuk orang asing adalah bagian dari rangkaian pembelajaran keterampilan berbahasa. Tujuannya adalah membantu siswa untuk mengulang, memantapkan segala sesuatu yang telah dipelajari, melatih kemampuan siswa untuk berpikir menggunakan logika bahasa Mandarin, serta menuangkannya dalam 
bentuk tulisan bahasa Mandarin atau lebih dikenal sebagai aksara Han (Zhao, 2006: 154). Di antara empat keterampilan berbahasa, meningkatkan kemampuan menulis adalah yang paling sulit, memerlukan pelatihan khusus (Zhao, 2006: 154). Hal tersebut dikarenakan kemampuan menulis terkait dengan penguasaan berbagai unsur kebahasaan dan non-kebahasaan itu sendiri (Iskandarwassid dan Sunendar dalam Devi, 2018: 106)

Penelitian ini merupakan sebuah pre eliminary study atau penelitian awal untuk pengembangan buku ajar keterampilan menulis bahasa Mandarin dalam pengajaran bahasa berdurasi panjang bagi pemelajar dewasa berbahasa ibu bahasa Indonesia yang belajar di lingkungan bahasanya sendiri. Materi-materi dalam buku ajar harus mendukung tercapainya kompetensi dan tujuan pembelajaran yang diharapkan, melalui topik dan kegiatan pembelajaran yang menunjang, penguasaan unsur kebahasaan dalam berkomunikasi, pengetahuan seni budaya Cina, dan lain sebagainya.

\section{Keterampilan Menulis Bahasa Mandarin}

Zhao (2006: 154) menyatakan bahwa menulis adalah sebuah kegiatan mengutarakan atau menyampaikan maksud secara tertulis. Kemampuan tersebut dapat dilakukan hanya jika seseorang memiliki dasar pengetahuan bahasa yang cukup baik. Salah satu yang dapat menambah dasar pengetahuan adalah dengan membaca, karena dapat menambah jumlah kosakata, pemahaman kalimat, yang diharapkan dapat diterapkan pada saat menulis. Oleh sebab itu, membaca dapat dikatakan sebagai tahap pertama dari pelatihan keterampilan menulis. Kegiatan menulis selain melibatkan ide gagasan penulis, juga melibatkan gerakan organ tubuh yang lain, yaitu tangan dan mata. Tulisan adalah bentuk keluaran tertulis yang ingin disampaikan oleh manusia, merupakan sebuah proses transfer dan pengkodean sistem pengetahuan yang rumit, juga merupakan sebuah proses penalaran yang rumit (Chen Changlai, 2005: 210).

Huang (2008: 176) berpendapat bahwa pengajaran keterampilan menulis bahasa Mandarin terdiri atas beberapa tahapan. Pada tahapan awal, fokus pelatihan adalah meniru. Hal tersebut akan membantu siswa terbiasa dan lebih memahami karakteristik bahasa Mandarin, baik aksara Han maupun kosakata serta aturan-aturan kalimat bahasa Mandarin. Siswa dapat menggunakan karangan-karangan bahasa Mandarin sebagai acuan pelatihan.

Menulis adalah keterampilan yang harus dilatih secara berulang dan berkesinambungan. Pelatihan keterampilan menulis dilakukan berdasarkan petunjuk dan arahan pengajar. Pengajar harus memberikan arahan atau panduan dengan benar dan jelas, agar latihan yang dilakukan dapat berjalan dengan baik, terarah, dan tepat. Pengajar juga harus memahami karakteristik bahasa Mandarin dan karakter bahasa ibu siswa. Hal ini dilakukan untuk menghindari kekeliruan pemilihan teknik dan topik pengajaran. Pengajaran menulis bahasa Mandarin dimulai dari yang mudah hingga yang sulit, yang sederhana hingga yang rumit, dimulai dari mengajarkan guratan dan radikal, aksara, kata, kalimat, paragraf, hingga wacana.

Keterampilan menulis dapat diajarkan pada satu mata kuliah terpisah maupun bergabung dalam mata kuliah yang lain. Hal ini dapat ditentukan dari latar belakang siswa, apakah pembelajaran untuk siswa yang belajar di jurusan bahasa Mandarin atau pembelajaran 
untuk siswa jurusan lain yang belajar bahasa Mandarin hanya sebagai salah satu mata kuliah. Pada pembelajaran bahasa Mandarin untuk siswa jurusan bahasa Mandarin, bahan ajar yang digunakan adalah bahan ajar khusus untuk keterampilan menulis, dimulai dari pembelajaran aksara Han. Siswa juga harus memahami pengetahuan dasar dan teknik menulis bahasa Mandarin. Siswa akan berlatih menggunakan kata, kalimat, tata bahasa, tanda baca dalam bahasa Mandarin. Dengan demikian, siswa menulis sebuah karangan berbahasa Mandarin yang baik dan benar sesuai dengan aturan penulisan bahasa Mandarin.

Pengetahuan dasar menulis sesuai kaidah penulisan yang tepat, serta teknik menulis menggunakan tata bahasa dan tanda baca yang tepat merupakan hal penting. Hal ini merupakan capaian pembelajaran mata kuliah Menulis. Siswa diharapkan dapat menyampaikan informasi melalui bahasa tulisan. Bahasa lisan dan bahasa tulisan memiliki persamaan dan perbedaan pada bahasa lisan, pembicara dapat secara langsung menggunakan beberapa cara seperti pengulangan, jeda, intonasi, penekanan untuk menyampaikan ide dan maksud. Sedangkan pada bahasa tulisan penulis dituntut untuk lebih tepat, jelas, teratur, logis dalam mememaparkan ide dan maksud. Penulis harus mencurahkan waktu dan pikiran untuk mempertimbangkan dan memutuskan kosakata, kalimat, aturan tata bahasa yang akan digunakan (Chen, 2005: 211).

\section{Tahapan pembelajaran keterampilan menulis bahasa Mandarin}

Menurut Zhao (2006: 156), pembelajaran keterampilan menulis terdiri atas 3 tahapan, yaitu:

1. Tahap dasar

Berdasarkan standar HSK yang ditetapkan oleh Hanban, pada tahap ini siswa diharapkan telah menguasai sekitar 700 karakter Han dan beberapa tata bahasa standar. Kesulitan umum yang dialami siswa pada tahapan ini adalah belum menguasai penulisan karakter Han, keterbatasan jumlah kosakata yang dikuasai, belum menguasai urutan struktur bahasa Mandarin. Oleh karena itu, titik berat pembelajaran keterampilan menulis pada tahap ini adalah menyusun kata menjadi kalimat, melatih struktur bahasa Mandarin. Pelatihan pada tahapan ini mengatasi kesalahan siswa menyusun kata menjadi kalimat yang tidak berterima dalam bahasa Mandarin.

\section{Tahap menengah}

Pada tahapan ini siswa telah menguasai sekitar 2000 karakter Han. Titik berat pelatihan keterampilan menulis pada tahapan ini adalah melatih siswa membuat karangan, dimulai dari menyusun kalimat menjadi paragraf, kemudian menjadi sebuah karangan. Kesulitan umum pada tahapan ini adalah kesalahan saat merangkaikan kata menjadi kalimat kemudian menjadi paragraf. Untuk penguatan kemampuan siswa pada tahapan ini adalah dengan melatih penguasaan kosakata siswa sebagai dasar untuk membuat kalimat dan menyusun menjadi karangan sesuai dengan logika berpikir dan bahasa. Target penguasaan pada tahapan ini adalah siswa dapat membuat karangan bahasa Mandarin yang baik dan tepat.

3. Tahap mahir

Pada tahap mahir, siswa telah menguasai sekitar 3000 karakter Han. Titik berat pelatihan keterampilan menulis pada tahapan ini adalah melatih siswa untuk dapat membuat 
sebuah karangan atau karya tulis yang memiliki tujuan khusus seperti cerita, tugas akhir, laporan, dan sebagainya. Pada tahapan ini siswa menguasai penggunaan bahasa yang sesuai dengan tema ataupun tujuan penulisan tersebut. Siswa selain dapat menulis dengan benar, juga harus dapat menulis dengan baik dan tepat sesuai dengan tujuan penulisan karangan atau karya tulis.

\section{METODE PENELITIAN}

Berdasarkan metode yang akan digunakan, jenis penelitian ini adalah penelitian pengembangan Research and Development. Penelitian ini merupakan penelitian awal berupa analisis kebutuhan buku ajar mata kuliah Menulis. Tahap selanjutnya adalah melakukan analisis materi dan menyusun ragangan untuk mengembangkan buku ajar mata kuliah Menulis. Hasil akhir dari dua tahapan penelitian ini adalah buku ajar Menulis yang disusun berdasarkan hasil penelitian. Pada penelitian tahap awal ini, instrumen penelitian berupa kuisioner dan daftar pertanyaan wawancara. Kuesioner yang digunakan dalam penelitian ini terdiri dari tiga jenis, yaitu (1) kuesioner kepada mahasiswa, (2) kuesioner kepada dosen, dan (3) kuesioner kepada Kaprodi/Korprodi. Instrumen penelitian berupa daftar pertanyaan tertulis atau lisan yang disusun berdasarkan pada standar CEFR untuk mengumpulkan informasi/data sebagai berikut:

1. Kuesioner kepada mahasiswa

1) Identitas pengisi kuisioner

a. Nama

b. Latar belakang pendidikan

c. Kewarganegaraan

d. Bahasa ibu

2) Mata kuliah keterampilan berbahasa Mandarin yang pernah diikuti

3) Identitas buku ajar yang digunakan

4) Tingkat kepuasan terhadap bahasa pengantar buku ajar

5) Tingkat kepuasan terhadap sistematika penyajian materi buku ajar (urutan kesulitan materi, teknik penyajian, fokus penjelasan)

6) Tingkat kepuasan terhadap soal-soal latihan

7) Tingkat kepuasan terhadap ketersediaan buku ajar (tempat pembelian, harga, dsb)

8) Tingkat kepuasan terhadap ketersediaan buku alternatif lain.

2. Kuesioner kepada dosen

1) Identitas pengisi kuisioner

a. Nama

b. Latar belakang pendidikan (strata dan bidang keahlian)

c. Kewarganegaraan

d. Bahasa ibu

2) Mata kuliah keterampilan berbahasa Mandarin yang pernah diampu

3) Judul mata kuliah keterampilan berbahasa dan konten

4) Identitas buku ajar yang digunakan

5) Tingkat kepuasan terhadap bahasa pengantar buku ajar

6) Tingkat kepuasan terhadap sistematika penyajian materi buku ajar (urutan kesulitan materi, teknik penyajian, fokus penjelasan) 
7) Tingkat kepuasan terhadap soal-soal latihan

8) Tingkat kepuasan terhadap buku instruksional untuk dosen pengampu

9) Tingkat kepuasan terhadap ketersediaan buku ajar (tempat pembelian, harga, dsb)

10) Tingkat kepuasan terhadap ketersediaan buku alternatif lain.

3. Kuesioner kepada Kaprodi/Korprodi

1) Identitas pengisi kuisioner

a. Nama

b. Latar belakang pendidikan (strata dan bidang keahlian)

c. Kewarganegaraan

d. Bahasa ibu

e. Asal prodi

2) Mata kuliah yang pernah dikelola

3) Judul mata kuliah keterampilan berbahasa dan konten

4) Identitas buku ajar yang digunakan

5) Tingkat kepuasan terhadap bahasa pengantar buku ajar

6) Tingkat kepuasan terhadap sistematika penyajian materi buku ajar (urutan kesulitan materi, teknik penyajian, fokus penjelasan)

7) Tingkat kepuasan terhadap ketersediaan buku ajar (tempat pembelian, harga, dsb) Tingkat kepuasan terhadap ketersediaan buku alternatif lain.

Penelitian ini melibatkan beberapa program studi yang melaksanakan pengajaran bahasa Mandarin, terutama prodi-prodi yang bernomenklatur Program Studi Pendidikan Bahasa Mandarin. Pelibatan prodi-prodi tersebut lebih mudah mengingat telah terbentuknya Asosiasi Program Studi Mandarin Indonesia (APSMI). Pada tahun 2017 ini, APSMI telah menaungi seluruh prodi yang melaksanakan pengajaran bahasa Mandarin di Indonesia sebagai anggota asosiasi. Khusus untuk Prodi Pendidikan Bahasa Mandarin, seluruhnya berada di bawah Divisi Pendidikan.

Oleh karena penelitian ini merupakan penelitian yang mengawali pengembangan buku ajar mata kuliah Menulis Bahasa Mandarin, secara umum data yang diperlukan adalah informasi tentang kebutuhan dan kepuasan penggunaan buku ajar yang digunakan pada mata kuliah Menulis Bahasa Mandarin pada prodi masing-masing selama ini.

Populasi penelitian ini terdiri atas mahasiswa, dosen, dan ketua program studi dari program studi Pendidikan Bahasa Mandarin di Indonesia, sedangkan sampel penelitian adalah mahasiswa, dosen, dan ketua Program Studi Pendidikan Bahasa Mandarin dari Universitas Negeri Jakarta, Universitas Bunda Mulia, Universitas Negeri Semarang, Universitas Widya Kartika, Universitas Negeri Malang. Universitas-universitas tersebut dipilih karena memiliki prodi bahasa Mandarin, baik kependidikan maupun non kependidikan.

\section{PEMBAHASAN}

Kuesioner untuk pengelola program studi, berjumlah 7 diisi oleh Universitas Negeri Semarang, Universitas Negeri Surabaya, Universitas Negeri Malang, Universitas Negeri Jakarta, Universitas Kristen Indonesia, Universitas Widya Kartika, dan Universitas Ma Chung. Kuesioner untuk dosen pengampu, berjumlah 6 diisi oleh Universitas Widya Kartika, Universitas Negeri 
Semarang, dan Universitas Negeri Jakarta. Kuesioner untuk mahasiswa, berjumlah 71 diisi oleh Universitas Negeri Malang, Universitas Bunda Mulia, dan Universitas Negeri Jakarta.

Hal lain yang perlu kami sampaikan, kondisi penggunaan buku ajar keterampilan berbahasa di setiap program studi berlainan. Kondisi penggunaan buku ajar yang dimaksud mencakupi jumlah dosen pengampu keterampilan berbahasa, pihak penentu pemakaian buku teks pada prodi, alasan penggunaan buku, bentuk/rupa buku teks keterampilan berbahasa, serta alasan penggunaan buku. Jumlah dosen pengampu mata kuliah Keterampilan Berbahasa Mandarin pada prodi kependidikan bahasa Mandarin yaitu: masing-masing sejumlah 14,28\% mempunyai 3 dosen pengampu, 4 dosen pengampu, 5 dosen pengampu, 6 dosen pengampu, dan 10 dosen pengampu. Sisanya 28,57\% mempunyai 7 dosen pengampu.

Pihak yang menentukan pemakaian buku teks pada prodi yaitu: masing-masing sejumlah $14,28 \%$ diskusi dosen pengampu, dosen pengampu, dan kepala program studi. Sejumlah $57,14 \%$ ditentukan oleh rapat prodi. Alasan penggunaan buku teks yang saat ini digunakan adalah sebagai berikut: (1) buku teks lengkap menyeluruh, terbitan dari universitas Cina; (2) buku teks terbukti dapat digunakan dosen untuk meningkatkan kemampuan mahasiswa berbahasa Mandarin; (3) buku relevan, menarik, up to date, mudah didapat; (4) buku relevan dan mutakhir; (5) buku terdiri atas seri yang relatif lengkap (kecuali percakapan), sehingga mudah untuk digunakan karena saling selaras. Dilihat dari segi kerangka pembelajaran, buku juga disusun dengan baik. Bahasa pengantar, penjelasan, serta jenis latihan kurang membantu siswa mencapai kompetensi per keterampilan berbahasa; (6) buku sesuai dengan perkembangan Cina, pengajaran dan pelatihan yang intensif sehingga membantu mahasiswa untuk meningkatkan kemampuannya.

Berikut penggunaan buku teks empat keterampilan berbahasa Mandarin yang saat ini digunakan, termasuk buku teks 《汉语阅读教程一年级第一册》 yang digunakan pada mata kuliah Menulis. Sebanyak 28,57\% berupa buku fotokopi; $14,28 \%$ berupa buku asli yang disusun oleh penulis luar program studi, dan $57,14 \%$ menggunakan buku fotokopi dan buku asli yang disusun oleh penulis luar program studi.

Mata kuliah keterampilan Menulis Bahasa Mandarin yang diselenggarakan oleh prodi responden memiliki perbedaan nama mata kuliah. Beberapa prodi tetap menggunakan nama "Menulis" dilengkapi tingkatan yang dituliskan menggunakan angka romawi, ada pula yang menggunakan istilah dalam bahasa Mandarin “汉语写作”. Berikut adalah penjabaran nama mata kuliah keterampilan Menulis beserta capaian pembelajaran dan jumlah pertemuan.

Tabel 1. Nama dan Capaian Pembelajaran Mata kuliah Keterampilan Menulis

\begin{tabular}{|c|c|c|c|l|}
\hline No & $\begin{array}{c}\text { Nama Mata } \\
\text { Kuliah }\end{array}$ & $\begin{array}{c}\text { SKS/TM per } \\
\text { semester }\end{array}$ & $\begin{array}{c}\text { Semester } \\
\text { pelaksanaan }\end{array}$ & \multicolumn{1}{|c|}{ Capaian Pembelajaran } \\
\hline 1 & Menulis I & $2 / 16$ TM & 1 & $\begin{array}{l}\text { Melatih keterampilan menulis dengan } \\
\text { memperkenalkan aksara Han dari segi } \\
\text { guratan yang mencakup guratan dasar, } \\
\text { menghitung jumlah dan menentukan } \\
\text { urutan guratan, pengenalan radikal } \\
\text { disertai informasi historis/latar belakang } \\
\text { dan filsafat yang merupakan dasar bagi }\end{array}$ \\
\hline
\end{tabular}




\begin{tabular}{|c|c|c|c|l|}
\hline & & & $\begin{array}{l}\text { keterampilan menulis pada tingkat } \\
\text { selanjutnya berupa kata-kata sederhana } \\
\text { dengan penguasaan kosa kata dan pola } \\
\text { kalimat sederhana setingkat HSK level 1. }\end{array}$ \\
\hline 2 & Menulis II & $5 / 16 \mathrm{TM}$ & 5 & $\begin{array}{l}\text { Mahasiswa dapat menulis teks sesuai } \\
\text { dengan tema yang diajarkan dengan } \\
\text { bahasa Mnadarin yang baik dan benar. }\end{array}$ \\
\hline 3 & Menulis III & $2 / 16 \mathrm{TM}$ & 3 & $\begin{array}{l}\text { Mahasiswa mampu menuliskan kalimat } \\
\text { dan teks pendek mengenai topik tertentu } \\
\text { sesuai dengan kaidah penulisan aksara } \\
\text { Cina sehingga menghasilkan tulisan yang } \\
\text { baik, penguasaan kosakata dan tata } \\
\text { bahasa sederhana setingkat HSK level 3 } \\
\text { (CEFR B1) }\end{array}$ \\
\hline 4 & $\begin{array}{l}\text { Hanyu } \\
\text { Xiezuo }\end{array}$ & $3 / 16 \mathrm{TM}$ & 4 dan 5 & $\begin{array}{l}\text { Meningkatkan kemampuan keterampilan } \\
\text { bahasa Mandarin tingkat menulis }\end{array}$ \\
\hline
\end{tabular}

Berdasarkan tabel tersebut, terlihat terdapat perbedaan pada nama mata kuliah keterampilan Menulis yang digunakan. Selain itu terlihat pula perbedaan jumlah sks dan pelaksanaan tatap muka perkuliahan. Hal ini terkait dengan perbedaan capaian pembelajaran yang berdampak pada perbedaan buku ajar yang digunakan.

Setiap tingkatan mata kuliah keterampilan Menulis memiliki capaian pembelajaran, di antaranya menguasai aturan dan pengetahuan dasar tentang guratan aksara, mampu menulis teks sesuai tema menggunakan bahasa Mandarin berdasarkan tingkatan HSK. Berdasarkan capaian pembelajaran yang diharapkan dapat dikuasai mahasiswa, prodi-prodi tersebut memilih menggunakan buku ajar sebanyak 20\% menggunakan 《汉语阅读教程一年级第一册》 terbitan Beijing Language and Culture University Press, 20\% menggunakan 《汉语写作教程》 terbitan Beijing Language and Culture University Press, 20\% menggunakan 《汉语综合写作教 程》terbitan Beijing University Press, 20\% menggunakan 《汉语阅读教程第二册》terbitan Beijing University Press, 20\% menggunakan buku kompilasi. Jika dilihat dari tahun terbit, buku yang digunakan untuk mata kuliah keterampilan Menulis terdiri atas $20 \%$ terbitan tahun 2002, 40\% terbitan tahun 2009, 20\% terbitan tahun 2010, 20\% terbitan tahun 2017.

Alasan prodi memilih buku-buku ajar tersebut untuk digunakan pada mata kuliah Menulis Bahasa Mandarin adalah (1) materi sesuai dengan kemampuan mahasiswa semester 5, (2) mengajarkan cara penulisan surat menyurat secara lengkap, (3) sesuai untuk mata kuliah keterampilan menulis, (4) rapat prodi telah memutuskan untuk menggunakan buku ajar tersebut. Adapun prodi yang memilih untuk membuat kompilasi buku ajar, dikarenakan bukubuku ajar yang sudah ada belum sesuai dengan capaian pembelajaran mata kuliah keterampilan Menulis pada prodi tersebut.

Di antara buku-buku ajar yang digunakan pada mata kuliah Menulis, sebagian besar prodi responden menggunakan buku ajar terbitan Beijing Language and Culture University Press. 
Pemilihan buku ajar mata kuliah Menulis juga mempertimbangkan tahun terbit, sehingga buku ajar yang digunakan tetap mengikuti perkembangan dan kemajuan zaman. Hal ini terlihat dari tahun terbit buku ajar yang digunakan oleh prodi-prodi tersebut berkisar pada tahun 2002 2017.

Jumlah pertemuan pada mata kuliah Menulis disesuaikan dengan jumlah sks, yaitu 2 sks dengan 16 pertemuan. Jumlah pertemuan tersebut direalisasikan dengan jumlah pokok bahasan yang disusun. Berdasarkan hasil penelitian, terdapat perbedaan jumlah pokok bahasan, yaitu 10 bab, 15 bab, 18 bab, dan 28 bab.

Selain buku-buku ajar utama tersebut, sebanyak $20 \%$ prodi yang menggunakan buku ajar tambahan, buku yang digunakan adalah 《发展汉语写作中级上》. Terdapat $40 \%$ prodi telah mengganti buku ajar yang digunakan, buku-buku yang sudah tidak digunakan adalah 《汉 语教程第一册上下》 terbitan Beijing Language and Culture University Press tahun 2009 dan "A Handbook of Compositions For Primary Schools" terbitan Singapore Asian Publications tahun 2002. Alasan buku-buku ajar tersebut tidak lagi digunakan adalah karena kurang sesuai untuk mata kuliah keterampilan Menulis I, tidak sesuai dengan capaian pembelajaran menulis teks dengan topik sederhana.

\section{Tingkat Kepuasan terhadap Buku Ajar}

Untuk mengetahui tingkat kepuasan terhadap buku ajar, peneliti membedakan menjadi 3 jenis, yaitu tingkat kepuasan dosen pengampu, tingkat kepuasan mahasiswa peserta, dan tingkat kepuasan pengelola (manajemen) prodi. Terkait dengan rincian hal yang menjadi pokok pembahasan tingkat kepuasan adalah materi ajar, penyajian, harga dan ketersediaan buku.

\section{Tingkat Kepuasan Dosen Pengampu Mata Kuliah Menulis Bahasa Mandarin}

Pada bagian kepuasan terhadap materi, terdapat 5 hal yang dinilai tidak puas, yaitu kedalaman materi ajar, isi materi ajar, tema materi ajar, kemampuan materi ajar memotivasi peserta didik, serta kelengkapan sistematika buku. Berikut adalah beberapa alasan ketidakpuasan dosen pengampu terkait materi: (1) kedalaman materi buku ajar dengan alasan bentuk teks kurang memotivasi dan melatih daya nalar siswa untuk membentuk kata, frasa kemudian kalimat dalam bahasa Mandarin, jumlah per bab agak timpang, tidak ada penjelasan tata bahasa, jika ada hanya ada contoh strukturnya tetapi kurang latihan tata bahasa; (2) isi materi dengan alasan keluasan materi buku ajar belum sesuai dengan tingkatan kelas dan tidak dikembangkan dengan menghubungkan dengan materi lain, isi materi buku ajar belum sesuai tingkatan dan kurang fokus untuk keterampilan menulis, kurang materi budaya dan sejarah, kurang materi visual, bentuk dan jumlah latihan menulis kurang, terdapat bagian materi yang tidak bisa diajarkan ke mahasiswa karena belum sesuai, seri buku belum lengkap, tidak ada terjemahan, jika pun ada kurang tepat penerjemahannya; (3) tema materi ajar dengan alasan tidak ada pembelajaran menulis yang sesuai tingkatan CEFR seperti ucapan singkat dan sederhana pada kartupos, mengisi identitas diri pada formulir, menulis catatan dan pesan singkat untuk kepentingan mendesak, menulis surat pribadi berdasarkan tahapan, dari kata ke frasa ke kalimat, menulis teks tentang topik umum atau hobi, menulis surat pribadi menjelaskan pengalaman dan kesan, menulis teks tentang hobi dengan jelas dan rinci, menulis esai atau laporan yang menginformasikan atau menjelaskan pendapat pribadi, menulis surat 
tentang peristiwa dan pengalaman tertentu, terdapat tema-tema yang tidak sesuai dengan zaman sehingga kurang menarik, kosa kata tidak mengikuti perkembangan zaman, belum terbarui; (4) kemampuan memotivasi keingintahuan peserta didik dengan alasan bentuk penjelasan pada setiap bab terasa kaku dan kurang memotivasi; (5) kelengkapan sistematika buku ajar dengan alasan tidak tersedia kunci jawaban.

Hal-hal yang dinilai kurang puas, yaitu kedalaman materi ajar, isi materi ajar, tema materi ajar, kemampuan materi ajar memotivasi peserta didik, serta kelengkapan sistematika buku. Berikut adalah beberapa alasan kekurangpuasan dosen pengampu terkait materi: (1) kedalaman materi buku ajar dengan alasan kurang dipertimbangkan kesesuaian untuk pembelajaran orang dewasa, tidak dicantumkan nama-nama radikal yang dianggap dapat membantu pembelajaran; (2) isi materi dengan alasan materi kurang fokus; jenis latihan menulis kurang beragam dan jumlahnya kurang; 3) tema materi ajar dengan alasan tidak ada pembelajaran menulis yang sesuai tingkatan CEFR seperti menulis ucapan singkat dan sederhana pada kartu pos seperti ucapan selamat hari raya; menulis catatan dan pesan singkat untuk kepentingan mendesak; menulis surat pribadi seperti ucapan terima kasih; pembelajaran guratan pada buku tingkat menengah; radikal, komponen karakter Han; ketepatan penulisan huruf, kata, diakritik ton; kosa kata tidak mengikuti perkembangan zaman, tidak terbarui; (4) kemampuan memotivasi keingintahuan peserta didik dengan alasan tidak terlihat buku tersebut dapat memotivasi siswa; (5) kelengkapan sistematika buku ajar dengan alasan tidak tersedia kunci jawaban.

Berikut adalah diagram persentase tingkat kepuasan Dosen Pengampu Mata Kuliah Menulis Bahasa Mandarin terhadap materi.

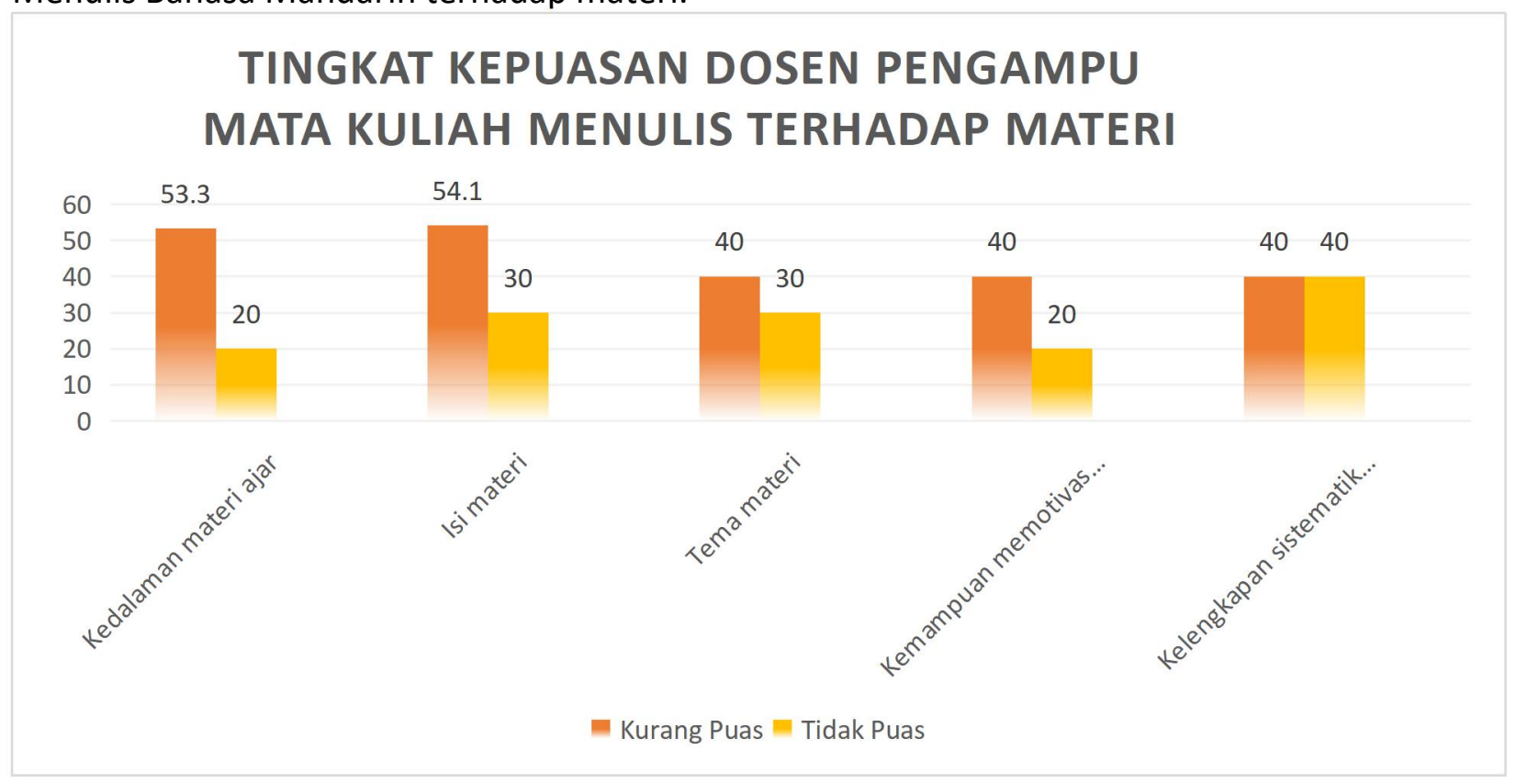

Pada bagian kepuasan terhadap penyajian, terdapat 7 hal yang dinilai tidak puas yaitu: kesesuaian penyajian teks, materi, tata letak, ilustrasi, pencantuman sumber kutipan dan 
ilustrasi, kemampuan memotivasi peserta didik, serta bahasa pengantar. Berikut adalah beberapa alasan ketidakpuasan dosen pengampu terkait penyajian materi: (1) kesesuaian penyajian teks dengan alasan teks yang dimunculkan kurang terkait dengan kompetensi menulis yang diharapkan, cara penyajian tidak mempertimbangkan kesulitan pemahaman siswa, kurang efektif; (2) materi dengan alasan ada beberapa yang tidak dicantumkan pada daftar kosa kata, jumlah kosa kata kurang banyak, tidak ada atau kurang penjelasan makna dan penggunaan kosa kata; tidak ada atau kurang penjelasan penggunaan tata bahasa secara rinci; kesesuaian tingkat kesulitan tata bahasa masih belum sesuai; terkadang bentuk latihan kurang variatif; tidak melatih kompetensi menulis sehingga terasa kurang sesuai; (3) tata letak dengan alasan masih dapat ditingkatkan; (4) ilustrasi dengan alasan masih kurang menarik; (5) pencantuman sumber kutipan dan ilustrasi dengan alasan tidak ada pencantuman; (6) memotivasi keterlibatan peserta didik dengan alasan tidak tahu tentang motivasi peserta didik; (7) bahasa pengantar dengan alasan bahasa pengantar yang digunakan kurang sesuai;

Hal-hal yang dinilai kurang puas, yaitu materi, tata letak, ilustrasi, pencantuman sumber kutipan dan ilustrasi, kemampuan memotivasi peserta didik. Berikut adalah beberapa alasan kekurangpuasan dosen pengampu terkait penyajian materi: (1) isi materi dengan alasan teks kurang melatih keterampilan menulis; jumlah latihan kurang banyak; tidak ada penjelasan dan contoh penggunaan tata bahasa; ragam latihan terasa monoton, tidak melatih kompetensi menulis siswa; isi latihan buku ajar kurang melatih kemampuan menulis siswa; materi pembelajaran ada yang tidak sesuai dengan kompetensi CEFR; (2) tata letak engan alasan masih belum maksimal; (3) ilustrasi dengan alasan tidak ada ilustrasi yang menarik; (4) pencantuman sumber kutipan dan ilustrasi dengan alasan tidak dicantumkan; (5) memotivasi keterlibatan peserta didik secara aktif (40\%) dengan alasan tidak dapat memotivasi.

Berikut adalah diagram persentase tingkat kepuasan Dosen Pengampu Mata Kuliah Menulis Bahasa Mandarin terhadap penyajian materi.

\section{TINGKAT KEPUASAN DOSEN PENGAMPU MATA KULIAH MENULIS TERHADAP PENYAJIAN MATERI}
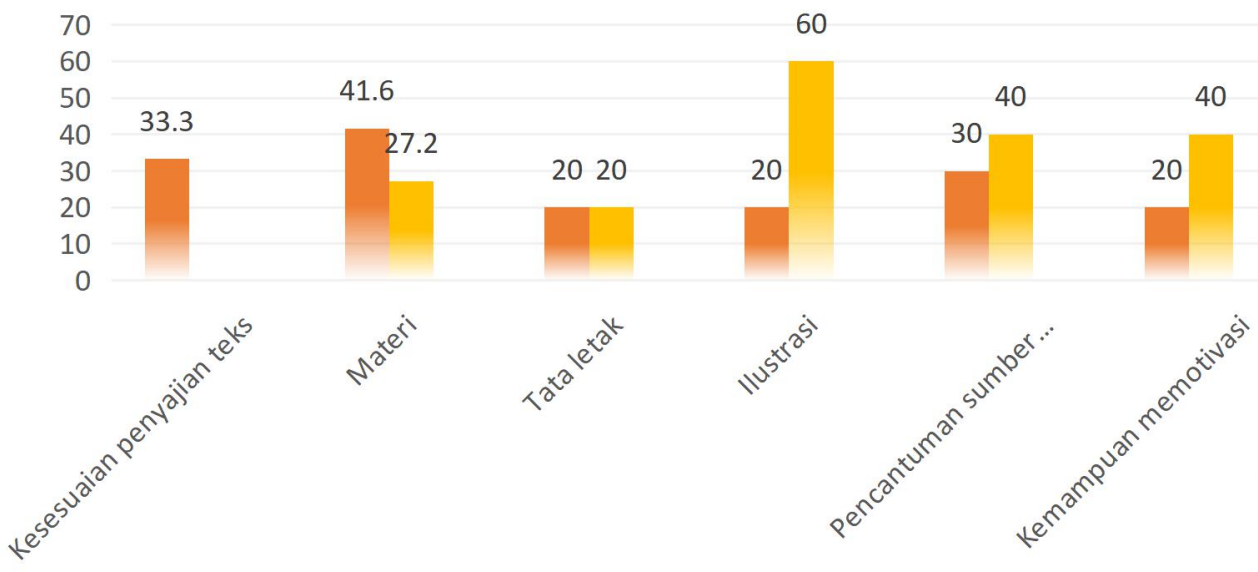

20
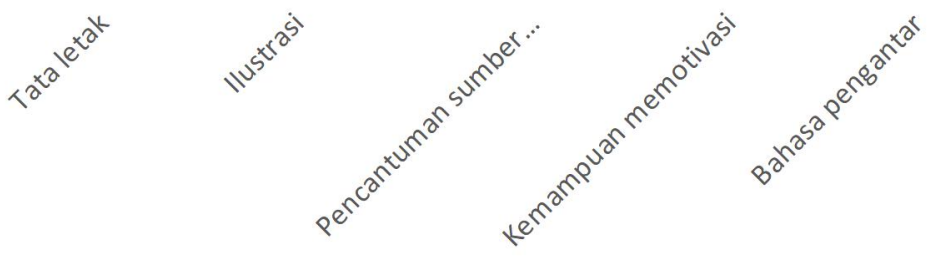

Kurang Puas $=$ Tidak Puas 
Pada bagian harga buku dan ketersediaan, terdapat 2 hal yang dinilai tidak puas yaitu harga dan ketersediaan. Adapun alasannya adalah harga buku terlalu mahal, buku tersebut belum ada di Indonesia sehingga harus diimpor langsung dari Tiongkok, waktu pemesanan yang cukup lama, serta jumlah distributor yang sedikit.

Berikut adalah diagram persentase tingkat kepuasan Dosen Pengampu Mata Kuliah Menulis Bahasa Mandarin terhadap harga dan ketersediaan buku.

TINGKAT KEPUASAN DOSEN PENGAMPU

\section{MATA KULIAH MENULIS TERHADAP}

\section{HARGA DAN KETERSEDIAAN BUKU}

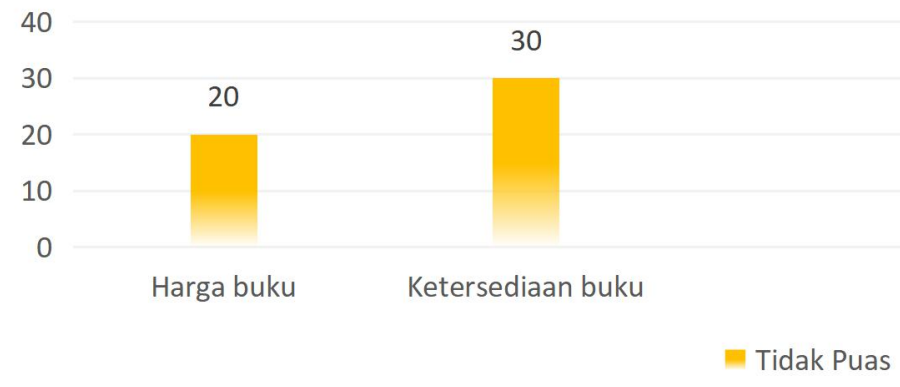

\section{Tingkat Kepuasan Mahasiswa Peserta Mata Kuliah Menulis Bahasa Mandarin}

Pada bagian materi ajar, hal-hal yang dinilai tidak puas adalah (1) tingkat kesulitan $(19,1 \%)$; (2) isi materi ajar (13,6\%); penulisan huruf, kata, diakritik ton (22,5\%).

Adapun hal-hal yang dinilai kurang puas pada bagian materi ajar, adalah (1) tingkat kesulitan (28,8\%); (2) isi materi ajar (31,1\%); penulisan huruf, kata, diakritik ton $(52,1 \%)$.

Berikut adalah diagram persentase tingkat kepuasan mahasiswa terhadap materi. 


\section{TINGKAT KEPUASAN MAHASISWA TERHADAP MATERI}

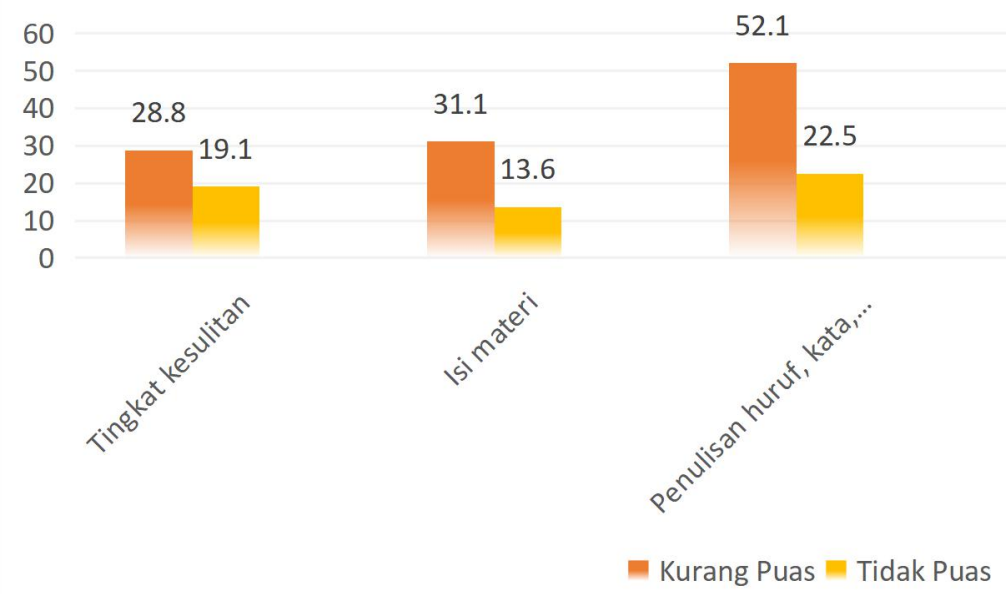

Pada bagian penyajian, hal-hal yang dinilai tidak puas adalah (1) sistematika isi buku $(15,9 \%)$; (2) isi materi $(7,1 \%)$; (3) tata letak $(7,1 \%),(4)$ ilustrasi $(7,1 \%),(5)$ pencantuman sumber kutipan dan ilustrasi (12,1\%); (6) bahasa pengantar (10\%).

Pada bagian penyajian, hal-hal yang dinilai kurang puas adalah (1) sistematika isi buku (44,9\%); (2) isi materi (26,7\%); (3) tata letak (34,3\%); (4) ilustrasi (30\%); (5) pencantuman sumber kutipan dan ilustrasi $(41,4 \%)$; (6) bahasa pengantar $(45,7 \%)$.

Berikut adalah diagram persentase tingkat kepuasan mahasiswa terhadap penyajian materi.

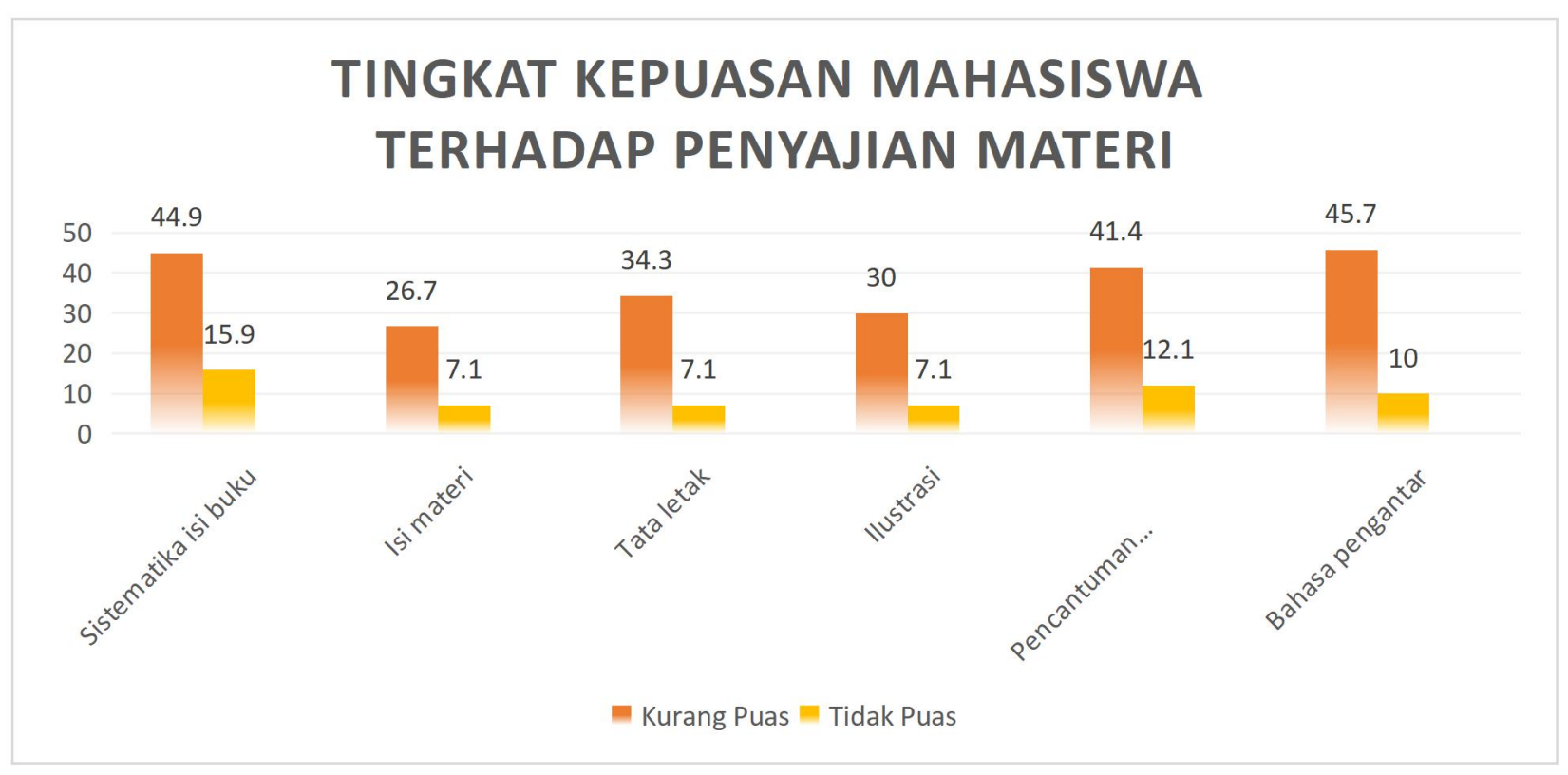


Pada bagian harga dan ketersedian buku, hal-hal yang dinilai tidak puas adalah (1) harga buku terjangkau (11,3\%); (2) buku mudah didapat di toko buku atau distributor $(4,3 \%)$.

Pada bagian harga dan ketersedian buku, hal-hal yang dinilai kurang puas adalah (1) harga buku terjangkau (28,2\%); (2) buku mudah didapat di toko buku atau distributor $(15,8 \%)$.

Berikut adalah diagram persentase tingkat kepuasan mahasiswa terhadap harga dan ketersediaan buku.

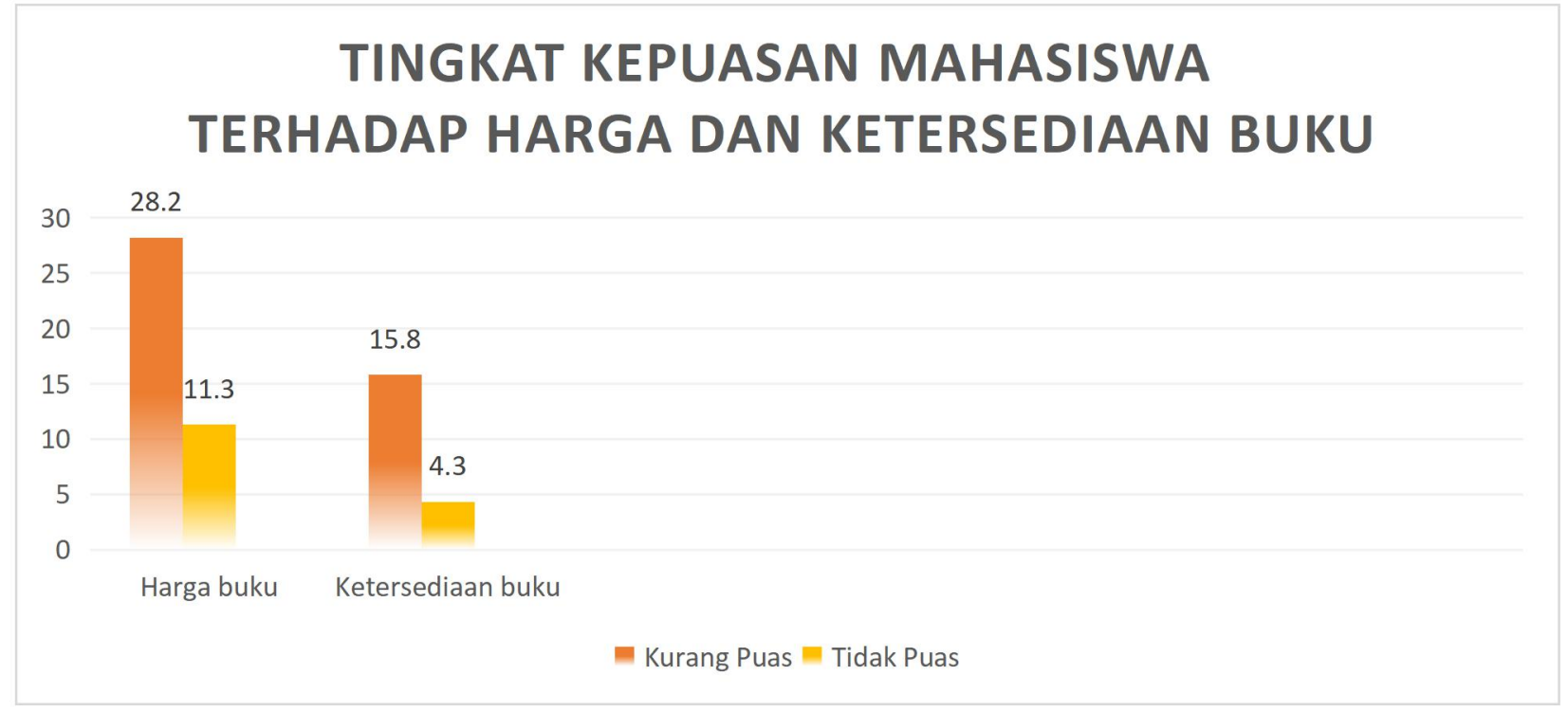

\section{Tingkat Kepuasan Pengelola (Manajemen) Prodi}

Sebagian besar prodi sudah cukup puas ataupun puas dengan buku ajar keterampilan berbahasa yang saat ini digunakan di prodi. Hal ini karena pemilihan buku tersebut sudah dipertimbangkan dan diputuskan agar sesuai dengan capaian pembelajaran mata kuliah, termasuk keterampilan Menulis. Namun ada pula hal-hal yang masih dirasa kurang memuaskan bagi pihak pengelola (manajemen) prodi. Hal-hal yang dinilai kurang puas adalah (1) harga buku keterampilan berbahasa Mandarin yang sedang digunakan di prodi terjangkau untuk mahasiswa (20\%) dengan alasan buku yang digunakan adalah terbitan Cina sehingga harus membeli dalam jumlah banyak dan dibebankan ongkos kirim yang mahal. Saat ini prodi tersebut menyiasati dengan fotokopi buku; (2) kemudahan akses untuk memperoleh buku keterampilan berbahasan Mandarin (20\%) dengan alasan cukup menyulitkan karena harus meminta bantuan orang lain yang sedang berada di Cina untuk membelikan kemudian diperbanyak di prodi.

\section{Kelebihan dan Kekurangan Buku Ajar yang Digunakan pada Mata Kuliah Menulis Bahasa Mandarin}

Alasan prodi memilih dan memutuskan untuk menggunakan buku ajar tentu telah mempertimbangkan kesesuaian materi dengan capaian pembelajaran.

\section{Kelebihan:}

1. Hierarki kesulitan teks, kosa kata, tata bahasa, latihan sudah cukup sesuai tingkatan kemampuan mahasiswa. 
2. Secara umum isi materi buku dan latihan dapat melatih keterampilan Menulis bahasa Mandarin.

3. Sistematika materi ajar dan kekonsistenan penyajian latihan dinilai sudah baik.

4. Buku-buku ajar yang digunakan sudah termasuk terbitan tahun terkini.

5. Tata letak baik.

\section{Kekurangan:}

1. Pada bagian materi ajar keterampilan Menulis, radikal, komponen karakter Han, guratan menjadi salah satu dasar pengetahuan yang penting. Namun pada beberapa buku ajar yang digunakan oleh prodi responden tidak memaparkan ataupun hanya sedikit memaparkan tentang pembahasan tersebut.

2. Jumlah latihan yang terdapat pada buku ajar masih belum maksimal melatih keterampilan Menulis.

3. Keragaman, keefektifan latihan juga masih terasa kurang. Latihan yang disajikan juga masih belum maksimal memotivasi peserta didik untuk berlatih keterampilan Menulis.

4. Terkait dengan latihan, tidak tersedia kunci jawaban latihan.

5. Buku ajar yang digunakan sudah tergolong pada periode yang terkini ( terbitan tahun 2002-2017), akan tetapi masih terdapat kosa kata yang belum mengikuti perkembangan zaman.

6. Materi buku ajar kekurangan akan materi visual. Jika melihat perkembangan pengajaran berbasis teknologi, banyak buku ajar yang sudah dilengkapi dengan materi visual.

7. Isi materi buku ajar masih terlalu sedikit membahas budaya dan sejarah.

8. Sebagian besar buku ajar yang digunakan merupakan terbitan Cina. Hal ini tentu berpengaruh pada harga dan ketersediaan buku ajar di prodi. Naik turun kurs mata uang, sangat mempengaruhi harga buku yang berdampak pada kemampuan siswa untuk memiliki buku ajar tersebut. Selain itu, dikarenakan harus diimpor dari luar negeri, maka buku-buku ajar tersebut belum tentu dapat dengan mudah didapatkan di toko-toko buku atau distributor.

\section{E. SIMPULAN}

Penyelenggaraan mata kuliah keterampilan Menulis di Program Studi Pendidikan Bahasa Mandarin di Indonesia memiliki berbagai perbedaan. Terkait dengan buku ajar yang digunakan, sebagian besar sudah melalui pertimbangan dan persetujuan pada rapat program studi tersebut. Berdasarkan berbagai pertimbangan, sebagian besar program studi menggunakan buku asli terbitan Cina, namun ada pula yang menggunakan buku fotokopi, dan buku kompilasi.

Saat ini buku ajar yang sedang digunakan oleh program studi responden mempunyai beberapa kelebihan seperti berikut: pertama, hierarki kesulitan teks, kosa kata, tata bahasa, latihan sudah cukup sesuai tingkatan kemampuan mahasiswa. Kedua, secara umum isi materi buku dan latihan dapat melatih keterampilan Menulis bahasa Mandarin. Ketiga, sistematika materi ajar dan kekonsistenan penyajian latihan dinilai sudah baik. Keempat, buku-buku ajar yang digunakan sudah termasuk terbitan tahun terkini. Kelima, tata letak baik.

Meskipun buku ajar yang digunakan memiliki berbagai kelebihan, terdapat pula beberapa kekurangan. Pertama, pada bagian materi ajar keterampilan Menulis, radikal, 
komponen karakter Han, guratan menjadi salah satu dasar pengetahuan yang penting. Namun pada beberapa buku ajar yang digunakan oleh prodi responden tidak memaparkan ataupun hanya sedikit memaparkan tentang pembahasan tersebut. Kedua, jumlah latihan yang terdapat pada buku ajar masih belum maksimal melatih keterampilan Menulis. Ketiga, keragaman, keefektifan latihan juga masih terasa kurang. Latihan yang disajikan juga masih belum maksimal memotivasi peserta didik untuk berlatih keterampilan Menulis. Keempat, terkait dengan latihan, tidak tersedia kunci jawaban latihan. Kelima, buku ajar yang digunakan sudah tergolong pada periode yang terkini ( terbitan tahun 2002 - 2017), akan tetapi masih terdapat kosa kata yang belum mengikuti perkembangan zaman. Keenam, materi buku ajar kekurangan akan materi visual. Jika melihat perkembangan pengajaran berbasis teknologi, banyak buku ajar yang sudah dilengkapi dengan materi visual. Ketujuh, isi materi buku ajar masih terlalu sedikit membahas budaya dan sejarah. Kedelapan, sebagian besar buku ajar yang digunakan merupakan terbitan Cina. Hal ini tentu berpengaruh pada harga dan ketersediaan buku ajar di prodi. Naik turun kurs mata uang, sangat mempengaruhi harga buku yang berdampak pada kemampuan siswa untuk memiliki buku ajar tersebut. Selain itu, dikarenakan harus diimpor dari luar negeri, maka bukubuku ajar tersebut belum tentu dapat dengan mudah didapatkan di toko-toko buku atau distributor.

Berdasarkan data yang diperoleh, terlihat beberapa hal yang perlu dicermati untuk pengembangan buku ajar mata kuliah Menulis. Pertama, kesesuaian teks, kosakata dengan perkembangan zaman, mengandung muatan budaya dan sejarah. Kedua, keragaman bentuk latihan serta kesesuaian jumlah. Ketiga, kejelasan kalimat penjelasan kosa kata, tata bahasa, contoh penggunaan. Keempat, kesesuaian materi buku ajar dengan capaian pembelajaran. Kelima, kelengkapan bagian buku ajar seperti materi visual, buku pegangan guru, kunci jawaban latihan. Keenam, pencantuman sumber kutipan.

Program Studi Pendidikan Bahasa Mandarin melalui penelitian analisis kebutuhan ini memperoleh berbagai informasi berkaitan dengan hal-hal yang dibutuhan untuk pengembangan buku ajar mata kuliah Menulis. Hasil penelitian ini selanjutnya dijadikan landasan untuk menganalisis materi ajar, perancangan dan penyusunan buku ajar mata kuliah Menulis.

\section{DAFTAR PUSTAKA}

[1] Brown, H. Douglas. Teaching by Principles An Interactive Approach to Language Pedagogy. New York: Pearson Education, 2007.

[2] Brown, J. D. 1995. The Elements of Language Curriculum: A Systematic Approach to Program Development. Boston: Heinle and Heinle.

[3] Chen Changlai. 2005. Duiwai Hanyu Jiaoxue Gailun. Shanghai: Fudan Daxue Chubanshe.

[4] Depdiknas.2008. Panduan Pengembangan Bahan Ajar. Jakarta: Direktorat Pembinaan Sekolah

Menengah Atas, Dirjen Manajemen Pendidikan Dasar dan Menengah, Depdiknas.

[5] Devi, Paramita Candra dkk. "Pengembangan Bahan Ajar Menulis Teks Prosedur Kompleks dengan Model Pembelajaran Discovery Learning Menggunakan Media Audio Visual (Video) Di Kelas XI SMA Negeri 1 Samarinda". Jurnal Diglosia. Volume 1 Nomor 2. Hal 101-112.

[6] Guojia Hanban. 2009.Guoji Hanyu Jiaoxue Tongyong Kecheng Dagang: Yinniyu, Hanyu 
Duizhao. Beijing: Waiyu Jiaoxue Yu Yanjiu Chubanshe.

[7] Huang Xiao Ying. 2008. Duiwai Hanyu Ketang Jiaoyu Yishu. Beijing: Beijing language and Culture

University Press.

[8] Tarigan, Henry Guntur. 2008. Menulis Sebagai Suatu Keterampilan Berbahasa.

Bandung: Angkasa.

[9] Xu Ziliang, Wu Renbu. 2005. Shiyong Duiwai Hanyu Jiaoxue. Beijing: Beijing Daxue Chubanshe.

[10] Zhao Jinming. 2006. Hanyu Keyi Zheyang Jiao - Yuyan Jineng Pian. Beijing: Shangwu Yinshuguan.

[11] Zhou Xiaobing (ed). 2009. Duiwaihanyu Jiaoxue Daolun. Beijing: Shangwu Yinshuguan.

\section{DATA PENULIS}

Nama

: Aprilia Ruby Wikarti, M.A.

Program studi

Perguruan tinggi

Telp.

Email

Nama

Program studi

Perguruan tinggi

Telp.

Email
: S 1 Pendidikan Bahasa Mandarin

: Universitas Negeri Jakarta

: 08979608797

: apriliarubyw.s@unj.ac.id

: Vanya Zelia

: S 1 Pendidikan Bahasa Mandarin

: Universitas Negeri Jakarta

: 081314567113

:vanyazelia@unj.ac.id 